\title{
DEMAND FOR MONEY AND HAYEKIAN TRIANGLES
}

\author{
PAVEL POTUZAK*
}

Fecha de recepción: 19 de noviembre de 2020

Fecha de aceptación: 12 de marzo de 2021

\section{Introduction}

Friedrich August von Hayek (1935) developed a specific business cycle theory in which interactions between the real and monetary sectors play a central role. In the first version of the theory, shocks to the money supply deflect market interest rate from the natural level and thus give false signals to entrepreneurs about relative demand between present goods and future goods. This idea was represented in a simple graphical tool, which was later called the Hayekian triangle. The structure of capital and the production process are depicted in a diagram that maps flows of resources from early stages of production to late stages, and finally to the hands of the consumer. On the basis of this theory, the preliminary recommendation for the monetary authority was to freeze the money supply in order to prevent fluctuations in the structure of production (Hayek 1928).

Hayek (1935) later realised that shocks to the demand for money may have similar effects as disturbances to the money supply. Shocks to the demand for money are reflected in changes of the

* Prague University of Economics and Business, Department of Economics, Namesti Winstona Churchilla 4, Prague, 130 67, Czech Republic, pavel.potuzak@vse. cZ, +420 224095358

The author would like to thank anonymous referees for helpful comments and acknowledge the support of grant VSEIGSF5/19/2020 provided by the Prague University of Economics and Business. 
velocity of circulation of money $(V)$. Hayek therefore specified a simple rule that does not require stabilisation of $M$ (money supply) but the entire term $M V$ in the equation of exchange. Such a rule would offset not only money-supply shocks but also shocks to the demand for money (Potuzak 2016b).

In his later work, Hayek (1941) elucidated in more detail the role of the demand for money during the business cycle. However, he had never used his triangles to depict processes within the structure of production when the economy is hit by the money-demand shock. This paper tries to fill this gap as it will demonstrate how changes in the demand for money might be reflected in the structure of production, depicted by the Hayekian triangles.

The first part of the paper briefly describes the Austrian business cycle theory with the help of the Hayekian triangles. The tenets of this theory are also sketched in the textbook IS-LM model. This Keynesian model is not only useful to translate the old-fashioned Austrian economic language into modern terms, but it also helps with identifying the impact of the money-demand shocks on the real economy. The second section uses the Hayekian triangles to demonstrate how changes in the money demand may affect the structure of production. It will turn out that the source of this change plays a crucial role. In other words, it is critical whether the change in the demand for money affects the demand for present goods (consumption) or for future goods (saving). Keynesian and Austrian tools give mutually inconsistent predictions, so the third section of the paper discusses the nature of the demand for money from the perspective of these two approaches. It is shown that the key distinction lies in the assumption whether money represents present goods or future goods. The fourth section extends the core analysis of the demand for money. The last part concludes the paper and recommends areas for future research.

\section{Money Supply Shock and the Austrian Business Cycle Theory}

Hayek (1935) distinguished two types of economic growth - sustainable and unsustainable. The former is caused by an increase in saving, the latter by a rise in the money supply. Suppose that the 
time preference of people permanently decreases. This fall is reflected by a relative shift of the demand for future goods as against present goods for the benefit of the former. In other words, people start to save more, which may decrease the interest rate on the market. Austrians argue that the natural rate of interest also falls since the time preference decreases. At the same time, factors of production are released from stages that produce consumption goods, i.e. from late stages of the production process. Lower costs of loanable funds motivate firms to invest in the creation of capital goods, which may be produced with factors of production that were released from the late stages. These capital goods will mature in final consumption goods in the future. It is believed that the eventual output of consumption goods will be larger, and the greater demand for future consumption goods will be thus satisfied. This process, according to Hayek, represents a version of "sound" economic growth in which the fall in the interest rate transmitted the key information about the change in the relative demand.

However, the increase in the supply of loanable funds may be also caused by a greater supply of money. A lower interest rate then delivers a signal of a greater demand for future goods, and firms may respond in a similar way as in the previous case. Compared to the first case, people have not reduced demand for present consumption goods, so factors of production may be attracted to early stages only due to greater demand stimulated by an artificial fall in the interest rate. New capital is being formed that will, however, mature into final consumption goods in the future. Labourers being paid with newly created money may not be patient enough to wait for these goods. The demand for present goods will be re-established at the initial relative level compared to the demand for future goods. The interest rate rises to the previous level, which reflects true time preferences of people and which is known as the natural rate. Resources attracted to the formation of future goods are now attracted back to the consumer's sectors. According to Hayek (1935), newly initiated capital structures cannot be completed and represent a pure waste of resources. Money supply expansion deflected the market interest rate from the natural level and provided a false signal about the relative demand for present as against future goods. 
This well-known Austrian story is reflected in Figure 1, which plots the structure of production in the Hayekian triangle (Hayek 1935, Garrison 2001, Huerta de Soto 2006). Panel (a) shows the initial lengthening of the structure of production that is motivated by the fall in the interest rate. Panel (b) depicts a surge in the demand for final consumption goods, an increase in the interest rate, and partial elimination of the newly created capital (shaded area).

\section{FIGURE 1, MONETARY EXPANSION AND THE STRUCTURE OF PRODUCTION}

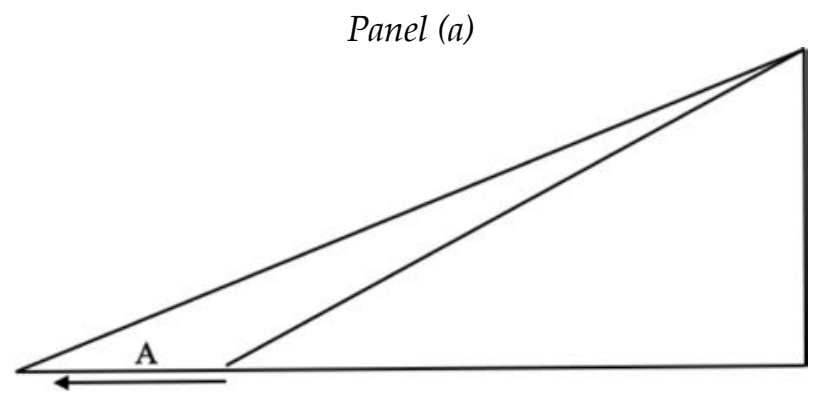

Note: Monetary expansion resulting in a decrease in the interest rate eventually leads to a more roundabout process of production (A).

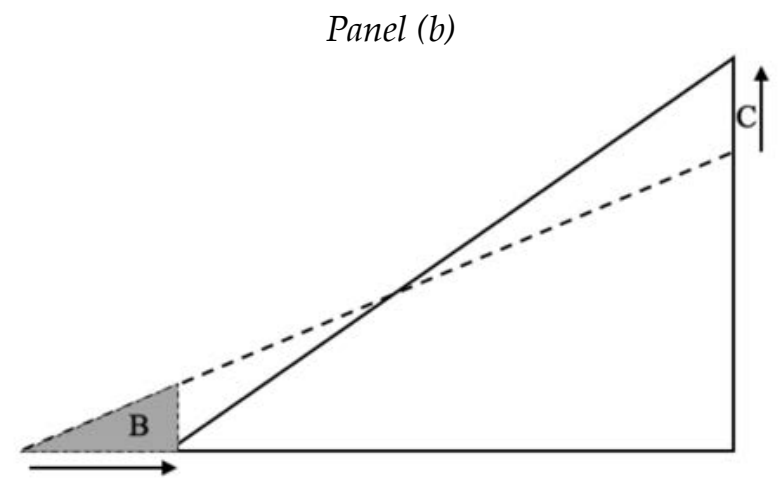

Note: The Hayekian triangle gradually draws up as the consumption demand is intensified (B). The increase in the interest rate "erases" the earliest stages of production (C). Source: Own construction 
Deflection of the market interest rate from the natural level can be also plotted in the textbook IS-LM model. Panel (a) in Figure 2 demonstrates that an increase in the money supply, which shifts the LM curve to the right, decreases the market interest rate $r_{2}$ below the natural level $r_{\text {nat }}$, which is defined by the intersection of the IS curve and the potential output $Y^{*}$ (Woodford 2003). Lower interest rate stimulates investment spending, which creates boom in the economy $\left(Y_{2}>Y^{*}\right)$.

FIGURE 2, MONETARY EXPANSION AND THE REVERSION OF THE INTEREST RATE

Panel (a)

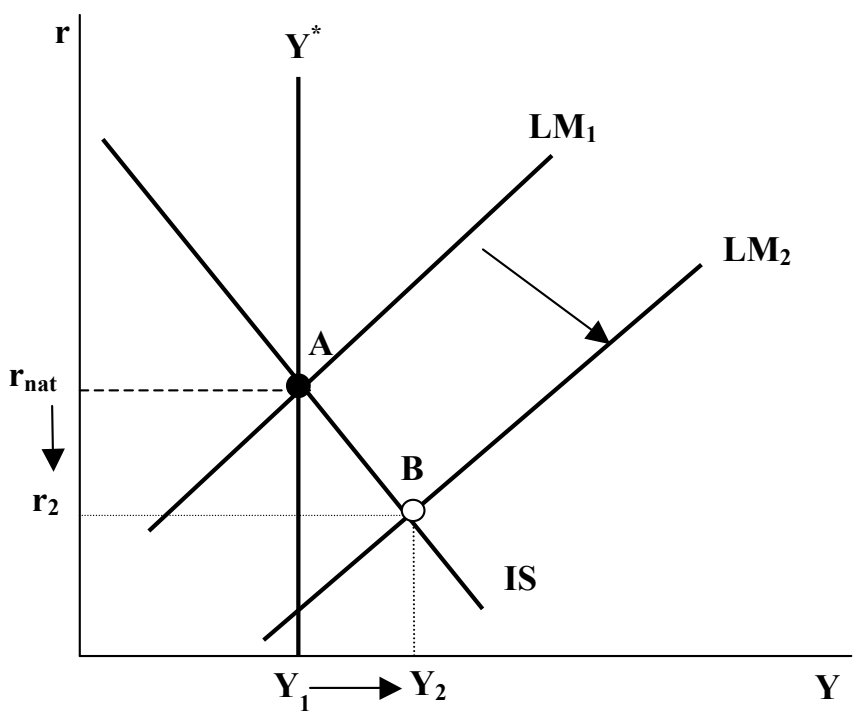


Panel (b)

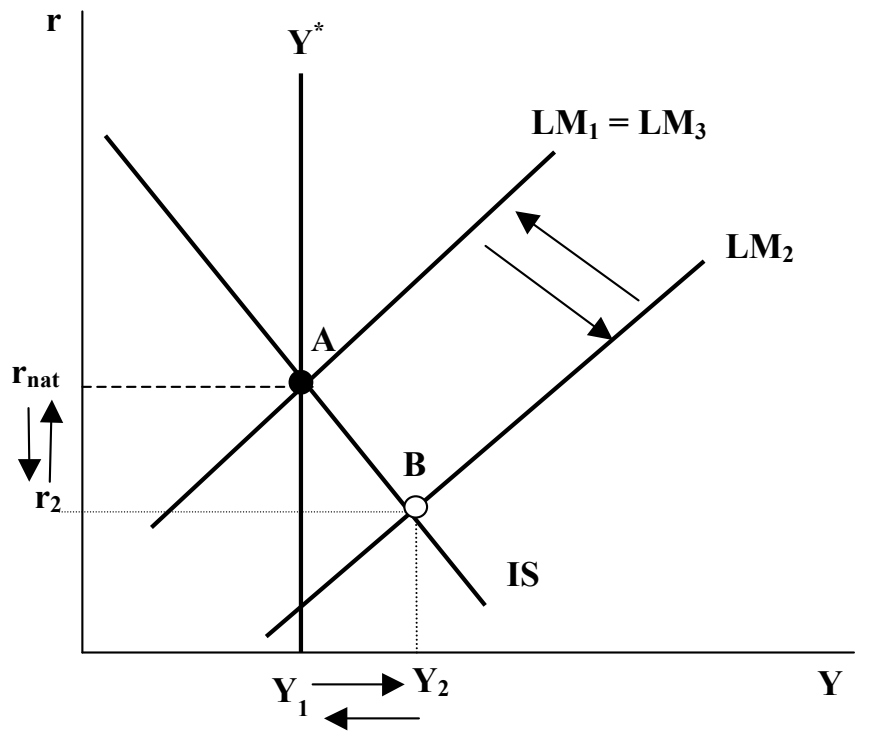

Panel (c)

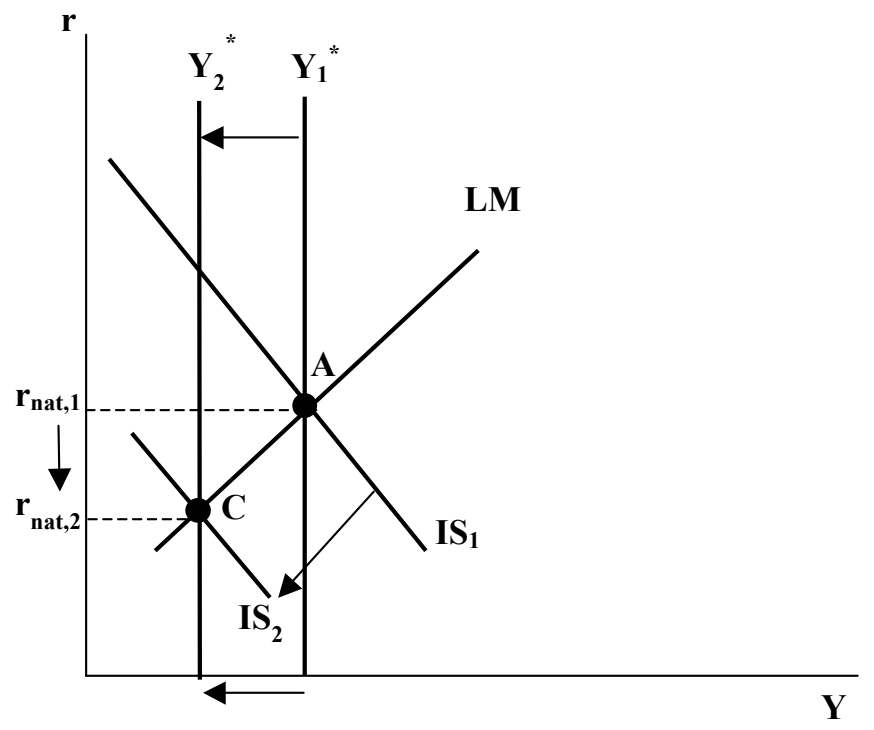

Source: Own construction. 
In the modern version, the economy cannot permanently sustain positive output gap, and the price level $(P)$ must rise. Higher $P$ reduces the supply of real money balances (increases nominal demand for money), which shifts the LM curve back to the initial position. Panel (b) also shows that the interest rate moves back to the natural level, and output returns to the potential.

Mainstream economics thus gives similar predictions as the Austrian theory. However, to make the IS-LM framework more consistent with the Hayekian theory, losses in capital structures should be reflected in the leftward shift of the potential output $Y^{*}$. This feature of the Austrian theory is plotted in panel (c), which also contains a fall in the IS curve representing disruption in the investment process. ${ }^{1}$ As can be seen, money supply shocks may leave permanent scars on the economy due to the misallocation of resources. Money is not neutral in the Austrian theory, as nominal shocks may affect natural levels of the key real variables.

\section{Demand for Money and the Business Cycle}

Similar effects as the increase in the money supply might have an autonomous fall in the demand for money. Suppose that a representative agent earns 10,000 monetary units (m.u.) every period, she spends $8,000 \mathrm{~m} . \mathrm{u}$. on consumption goods, and saves 2,000 m.u. in the form of new purchases of bonds. Assume that she owns $20,000 \mathrm{~m} . \mathrm{u}$. in money balances. Her flow of income is constant over time as well as the split of her income between consumption and saving. She does not change her money balances either, so such a state can be called a steady state, or an evenly rotating economy (Mises 1996).

Now suppose that she decides to reduce her money balances from 20,000 m.u. to 19,000 m.u., and she buys additional bonds for 1,000 m.u., i.e. her demand for future goods rises (from 2,000 m.u.

\footnotetext{
${ }^{1}$ In recession, the natural rate of interest most probably falls. Furthermore, the LM curve is surely also affected. The reason might be a partial collapse of deposits and the money supply, shifting the LM curve to the left, which creates pressures in the form of "secondary" deflation.
} 
to 3,000 m.u.). However, her demand for present real consumption goods remains the same ( 8,000 m.u.). This shock represents an autonomous decrease in the demand for money. If the majority of agents act in a similar way, the interest rate on the loanable funds markets falls due to a larger supply of loanable funds. Effects of this decision should be similar to the increase in the money supply. In the equation of exchange, $V$ rises instead of $M$.

The fall in the interest rate triggers longer methods of production. Demand for real present consumption goods was not diminished, so early stages may attract factors of production only due to the intensified demand for future goods from released money balances. However, when money flows eventually back to the hands of labourers-consumers, the initial ratio between demand for present goods and future goods must be re-established (80:20). Furthermore, a gradual increase in prices that accompanies this general rise in demand will sooner or later reduce motivation of people to dissolve their money balances. The source of additional demand for future goods will be exhausted. The structure of production tends to move to the initial shape, and part of the initiated longer processes will be abandoned.

As a result, the economy undergoes a similar business-cycle pattern as in Figures 1 and 2. The only difference is that the shock was triggered by a fall in parameter " $\mathrm{k}$ " in the usual form of the demand for money $(M d=k P Y)$, i.e. increase in $V$ rather than by an increase in the money supply $M$. This is the reason why Hayek (1935) recommended to stabilise the term $M V$ in the equation of exchange to prevent economic fluctuations.

Another difference compared to the boom caused by the money-supply expansion is the magnitude of economic fluctuations that might be initiated by a fall in the demand for money. Credit capacity of the banking system is almost unlimited, whereas the amount of money balances out of which people may spend their "cash" reserves is rather limited. At the same time, it is not very likely that people will suddenly change their liquidity preference to such an extent to trigger recognisable and measurable economic fluctuations. It is rather the other way round - the course of the business cycle and economic instability cause shocks to the demand for money. 
Nevertheless, this example does not represent the only way in which the change in the demand for money may emerge. Suppose that the representative agent reduces her money balances from 20,000 m.u. to 19,000 m.u., but instead of bonds (greater demand for future goods - saving) she decides to buy real consumption goods. Thus, her demand for present goods rises from 8,000 m.u. to 9,000 m.u.

\section{FIGURE 3, INCREASE IN CONSUMPTION DEMAND FROM RELEASED MONEY BALANCES}

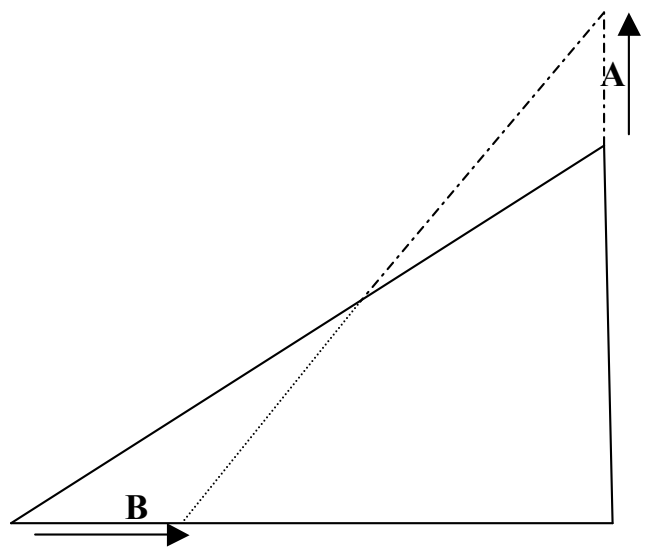

Note: Increase in demand for consumption goods raises prices in late stages (A), and the structure of production is temporarily shortened (B).

Source: Own construction.

Figure 3 shows that stages close to final consumption experience a positive demand shock. Factors of production are motivated to move from early stages to late stages. It is a similar shock as if the increased supply of money was spent on consumption goods. Hayek (1935) and Garrison (2001) argue that the business cycle will occur as well, but it will be of much lower intensity compared to the traditional Austrian case when the creation of new capital structures is initiated. In this case, the re-establishment from shorter back to longer methods will not be as painful. Due to irreversibility of time (Hayek 1941) it is easier to make future goods from present goods rather than the other way round. 
The reversion to the initial structure of production and to the relative demand between present goods and future goods (80:20) must occur since the time preference of people has not changed. The (nominal) demand for money must be stabilised at the previous level of 20,000 m.u. due to a general increase in prices. The source for an extra demand for real consumption goods disappears.

A third case might be a proportional increase in saving as well as consumption encouraged by a fall in the demand for money. Suppose that consumption demand rises to 8,800 m.u. and saving to 2,200 m.u. (so the ratio between consumption and saving remains $4: 1$ ) financed by a decrease in money balances from 20,000 m.u. to 19,000 m.u. The structure of production may experience a general increase in demand, which is depicted in Figure 4.

FIGURE 4, INCREASE IN DEMAND FOR BOTH PRESENT AND FUTURE GOODS FROM RELEASED MONEY BALANCES

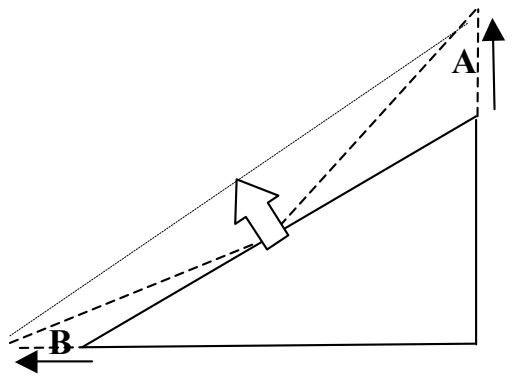

Note: Increase in demand for consumption goods raises prices in late stages (A). Increase in saving results in lengthening of the structure of production (B). Source: Own construction.

It is a tough question how these two cases (Figures 3 and 4) might be depicted in the textbook IS-LM model. Figure 5 shows that a fall in the demand for money shifts the LM curve to the right, the increase in the consumption demand moves the IS curve in the same direction. The economy is booming $\left(Y_{2}>Y^{*}\right)$, and the interest rate remains at the previous level. Thus, this might correspond to 
the Hayekian triangle in Figure 4 where the slope of the triangle, which represents the interest rate, remains constant.
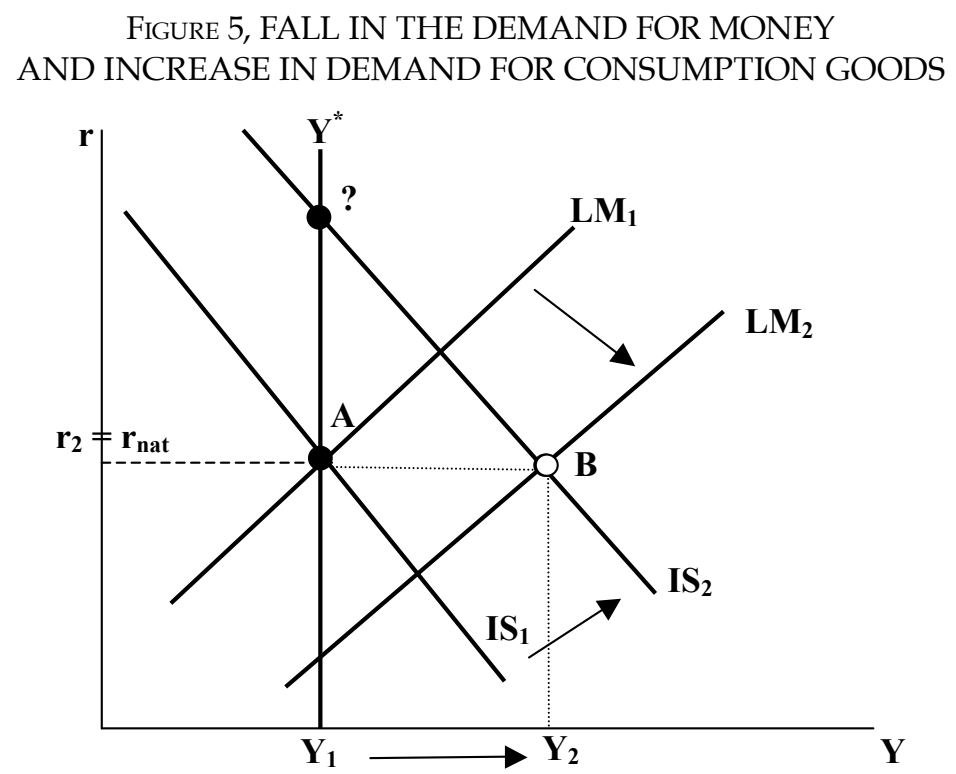

Source: Own construction.

However, the Austrian understanding of the natural rate of interest is then at odds with the (new) Keynesian definition in the IS-LM model. Figure 5 indicates that the natural rate of interest, which is determined by the intersection of the IS curve and potential output $Y^{*}$, increases. The Austrians, as well as the neoclassical/Wicksellian approach, conclude that a change in the demand for money should not affect the natural rate of interest, which is determined by the time preference of people (real saving) and/or marginal productivity of capital (real investment). ${ }^{2}$ This question will be solved in

2 A similar problem with the definition of the natural rate of interest arises in modern DSGE models when the IS curve depends on real money balances. This may happen when the utility function contains real money balances $M / P$, and $M / P$ and 
section 4 as it requires a thorough discussion about the nature of money from the perspective of the two approaches.

\section{The Nature of Money Demand from the Misesian and Keynesian Perspective}

The usual textbook IS-LM model is based on the Keynesian (1936) idea that the allocation of income between consumption and saving depends on the "fundamental psychological law" rather than on the interest rate. The rate of interest then determines how much of this saving will be kept in the form of money and how much in the form of interest-yielding illiquid assets such as bonds. In other words, a change in the interest rate will not affect the total volume of saving, but rather the structure of saving. It is obvious that this approach emphasizes the role of money as a store of value. In other words, it can be argued that the Keynesian perspective assumes that money is a future good (Cochrane and Call 1998), as is depicted in Figure 6. Figure 7 plots the role of the interest rate in this theory.

FIGURE 6, THE KEYNESIAN APPROACH

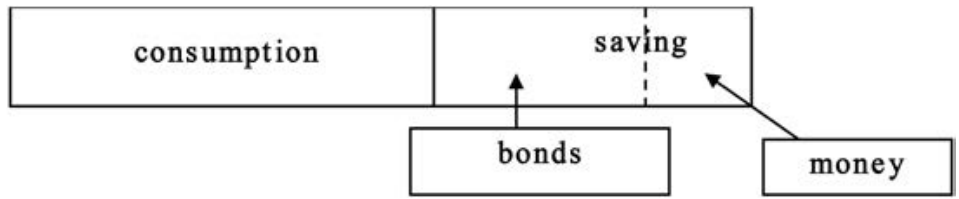

Note: The fundamental psychological law determines how income is split between consumption and saving. The interest rate determines the allocation of saving between bonds and money.

Source: Own construction

consumption $C$ are not additively separable in the utility function. The Euler equation, from which the New Keynesian IS curve is derived, then depends on real money balances (McCallum 2001). A similar question will appear when we allow for the Pigou effect, which causes a shift of the IS curve when real money balances change. 
FIGURE 7, THE INTEREST RATE INCREASE IN THE KEYNESIAN THEORY

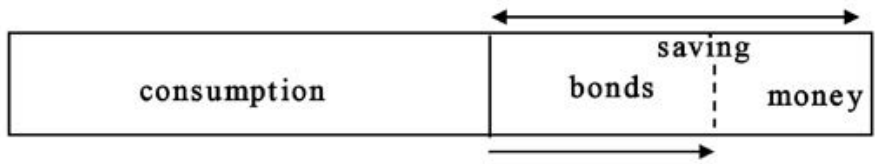

An Increase in the interest rate:

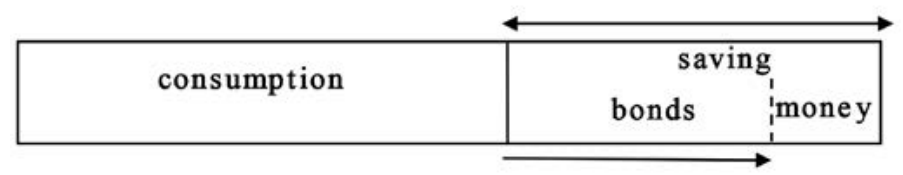

Source: Own construction

Case 1 in the previous section represented a fall in the demand for money for the benefit of purchases of bonds. This shock is depicted in Figure 2. People did not change their consumption (IS curve was not affected), only the form in which they wish to save (LM shifted). Figure 5 shows a shift of the IS curve since released money balances were also used to purchase consumption goods, not only bonds. This represents case 3 (or 2 ) from the previous section.

On the other hand, Austrian economists, such as Mises (2009, 1996) and Rothbard (2004), stress that money is a present good par excellence since it can be readily used for purchases of present consumption goods (Cochrane and Call 1998, 2000). ${ }^{3}$ Thus, the role of money as the medium of exchange is emphasized. Furthermore, the interest rate plays a critical role in the allocation of income between present goods (consumption) and future goods (saving).

Figure 8 shows that money balances are included in the set of present consumption goods. An increase in the interest rate reduces demand for present goods. This may have a form of the

3 Yet, Barnett and Block (2005) argue that money is a producers' good, thus a future good, by stressing that exchange (of ownership rights to a consumption good) is a form of production. 
lower demand for real present consumption goods (middle rectangle in Figure 9), lower demand for money balances (bottom rectangle in Figure 9), or a combination of both.

FIGURE 8, THE MISESIAN APPROACH

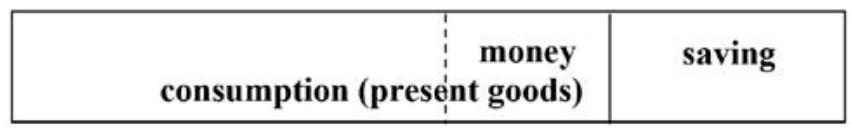

Note: The interest rate determines how income is split between consumption and saving

Source: Own construction

FIGURE 9, THE INTEREST RATE INCREASE IN THE MISESIAN THEORY

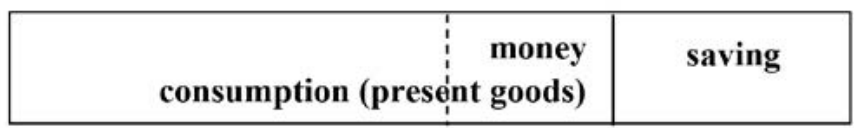

An increase in the interest rate:
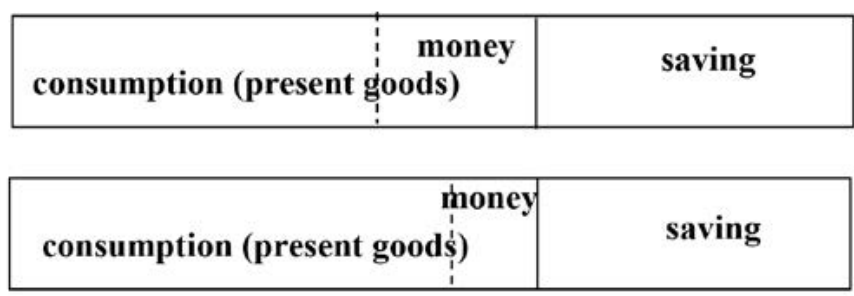

Source: Own construction

In the Austrian perspective, the natural rate of interest might be affected only if the relative demand between present real consumption goods and future real consumption goods (saving) 
changes. This may occur if the time preference of people (Mises 1996, Rothbard 2004) or if productivity of roundabout methods of production, i.e. productivity of capital (Hayek 1941), change. Shocks to liquidity preference (velocity shocks) should have no impact on the natural rate of interest. These liquidity-preference shocks might have various business cycle repercussions that are, however, of much lower importance than those caused by the money supply shocks.

\section{Further Considerations about the Demand for Money}

To complete the picture about the demand for money, this section briefly discusses other forms of shocks. A representative agent may hoard more money rather than dissolve cash balances, which was discussed in section 2. From the flow of her income, she can suddenly keep additional 1,000 m.u. in order to increase money balances from 20,000 m.u. to 21,000 m.u. This increase in the demand for money may either restrict consumption from 8,000 to 7,000 , reduce saving from 2,000 m.u. to 1,000 m.u., or decrease both in the respective interval.

In the former case, late stages of production would experience a negative shock, which releases factors of production on the market. The Hayekian triangle tends to be flatter. However, it must eventually re-establish its initial shape as the general fall in prices, caused by a decrease in demand for goods, lowers motivation of people to hoard money from their incomes.

In the latter case, people would hoard money by restricting their purchases of bonds. Early stages of production, creating future goods having today the form of capital goods, suffer from a negative demand shock. The Hayekian triangle will become steeper, and some longer projects might be abandoned. At the end of the day, however, the structure of production will move to the initial shape, as the greater demand for money will be "satisfied" by a lower general level of prices.

The transitory steeper shape of the Hayek triangle in this latter case suggests that the interest rate on the market may rise above the natural level. A similar conclusion can be derived from the 
IS-LM model, in which the LM curve shifts to the left, as the demand for money rises. The former case (hoarding money by restricting consumption) would be consistent with a simultaneous leftward shift of the IS and LM curves since the demand for consumption goods drops. It is then unclear what the impact on the interest rate would be.

The very last consideration will be about an exogenous shock to technology, which suddenly raises productivity of capital and increases the investment demand. The natural rate of interest rises after this shock. Hayek (1933) proposed that this is the most prevalent trigger of the business cycle since the banking system might be sluggish in increasing the market interest rate to the new level of the natural interest rate (Cassel 1928).

The banking system will accommodate this higher investment demand by the creation of new money. Thus, instead of the increase of the real saving on the part of consumers by their restriction of real consumption, which would be a sustainable response of the economy to greater investment demand, banks provide sufficient amounts of newly created money to finance new investment projects. In the IS-LM diagram, the rightward shift of the IS curve will be followed by a corresponding shift of the LM curve.

This action, according to Hayek (1933), triggers unsustainable re-structuring of the production process and initiates business cycle. In this case, the deviation between the market and natural interest rate is not induced by a fall of the former, but by an increase in the latter (Wicksell 1977). The fall of the market interest rate due to a deliberate action of the central bank is a naïve story, which might only illustrate the tenets of the theory (Hayek 1933,1935).

Considerations about the demand for money might also fit this extended analysis. When the interest rate tends to increase due to an investment shock, people might release part of their money balances without restricting their real consumption. New investment projects will be enabled by higher $V$ rather than by larger $M$, but consequences might be similar. In the IS-LM model, this high sensitivity of the demand for money with respect to the interest rate is represented by a very flat LM curve. A rightward shift of the IS curve, caused by the positive investment shock, leads to a large increase in output (beyond the potential level) rather than the 
interest rate, whose increase lags behind the level of the new natural interest rate (Potuzak 2016a, 2018).

As was argued in chapter 3 , the magnitude of this deviation might be smaller since the space for changes in the money demand is rather limited compared with credit capacities of the banking sector. Nevertheless, the Austrian business cycle is possible even in the world of the fixed money supply if the demand for money is sufficiently sensitive or unstable.

\section{Conclusion}

This paper shows that the Austrian business cycle theory may be generalized to changes in the demand for money. Exogenous shocks on the demand side of the money market might have similar effects as the money supply shocks. The key reason lies in the fact that the autonomous money-demand changes affect the relative demand between present goods and future goods, which may deflect the market rate of interest from the natural level. This consequently triggers reallocation of factors of production from late stages of production to earlier stages or vice versa. The paper demonstrates that the impact on the structure of production depends on the paths through which hoarding, or dishoarding, operate. If, for example, a lower demand for money is reflected in greater purchases of bonds, this larger flow of savings temporarily stimulates production in early stages of production. New capital structures, however, cannot be completed, as the demand for money gradually grows to the initial level encouraged by higher prices.

The analysis shows that it is not perfectly clear how changes in the demand for money affect the interest rate and whether they can even modify the natural level of this key price in the economy. The Austrian approach and the Keynesian theory provide irreconcilable predictions because the nature of money is considered differently. In this connection, it was discussed whether money represents present goods, which is favoured by the Misesian explanation, or future goods, which is stressed by the Keynesian liquidity preference theory. 
The answer would be even more complicated when one allows money to be included in the utility function along with consumption. The resulting definition of the natural rate of interest then opens areas for new research that might integrate findings of old masters of economics, such as Hayek and Keynes, with the modern DSGE approach.

\section{BIBLIOGRAPHICAL REFERENCES}

Barnett, W. and Block, W. E. (2005): "Money: Capital Good, Consumers' Good, or (Media of) Exchange Good?," The Review of Austrian Economics, Vol. 18, No. 2, pp. 179-194.

Cassel, G. (1928): “The Rate of Interest, the Bank Rate, and the Stabilization of Prices," The Quarterly Journal of Economics, Vol. 42, No. 4, pp. 511-529.

Cochran, J. P. and Call, S. P. (1998): "The Role of Fractional-Reserve Banking and Financial Intermediation in the Money Supply Process: Keynes and the Austrians," The Quarterly Journal of Austrian Economics, Vol. 1, No. 3, pp. 35-50.

- (2000): "Free Banking and Credit Creation: Implications for Business Cycle Theory," The Quarterly Journal of Austrian Economics, Vol. 3, No. 3, pp. 29-40.

Garrison, R.W. (2001): Time and Money, The Macroeconomics of Capital Structure, London and New York, Routledge.

Hayek, F. A. von (1928): "Intertemporal Price Equilibrium and Movements in the Value of Money," In F. A. Hayek. Money, Capital, and Fluctuations: Early Essays, edited by Roy McCloughry, Chicago, University of Chicago Press, 1984.

- (1929): Monetary Theory and the Trade Cycle, London, Jonathan Cape [1933].

- (1931): Prices and Production, New York, Augustus M. Kelly Publishers [2nd edition 1935].

- (1941): The Pure Theory of Capital, Chicago, The University of Chicago Press.

Huerta de Soto, J. (1998): Money, Bank Credit, and Economic Cycles, Auburn, Alabama, Ludwig von Mises Institute [ $4^{\text {th }}$ English edition 2020]. 
Keynes, J. M. (1936): The General Theory of Employment, Interest and Money. Harcourt, Brace and Company.

McCallum, B. T. (2001): “Monetary policy analysis in models without money," Review, Federal Reserve Bank of St. Louis, July, pp. $145-164$.

Mises, L. von (1912): The Theory of Money and Credit, Auburn, Alabama, Ludwig von Mises Institute [2009].

- (1949): Human Action: A Treatise on Economics, San Francisco, Fox \& Wilkes [4th edition 1996].

Potuzak, P. (2016a): The Dynamics of the Interest Rate in the Austrian Business Cycle Theory, available at SSRN: https://ssrn.com/ abstract $=2891641$.

- (2016b): Hayek MV-Rule, available at SSRN: https://ssrn.com/ abstract $=2857719$.

- (2018): "Price Level Stabilization: Hayek contra Mainstream Economics," Prague Economic Papers, Vol. 27, No. 4, pp. 449-478.

Rothbard, M. N. (1962): Man, Economy, and State, Auburn, Alabama, Ludwig von Mises Institute [2004].

Wicksell, K. (1906): Lectures on Political Economy, Volume 2, Fairfield, New Jersey, Augustus M. Kelley Publishers [1977].

Woodford, M. (2003): Interest and Prices: Foundations of a Theory of Monetary Policy, New Jersey, Princeton University Press. 